\title{
Legal Reform and Struggles Against Precarity: The Case of State Workers' Early Retirement in Vietnam
}

\author{
Tu Phuong Nguyen
}

\begin{abstract}
This paper contributes to the literature on precarity in Asia by examining the way in which state law interacts with social, political, and ideological factors in shaping experiences of precarity. Different from studies of precarity that see law as a set of state regulations underpinning the precarious economic and political status of individual workers, this paper adopts a socially grounded view of law that incorporates workers' understandings of and engagements with state law in commonplace settings. It also adopts a view of precarity as a complex dynamic of social, legal, and political processes shaping and reproducing workers' experiences of insecurity and vulnerability at work, rather than a broad, identity-based category of non-standard and informal types of employment. Through an ethnographic study of former state workers' working experiences in Vietnam, this paper sheds light on different aspects of workers' collective and individual struggles against precarity and workplace injustice, and the role that law plays in these struggles. It argues that law contributes to reinforcing workers' precarious experiences, which are underpinned by the tension between their expectations grounded in the socialist era and the realities of workplace injustice and insecurity in a market economy.
\end{abstract}

Keywords: precarity, social insurance, state workers, law, Vietnam

DOI: $10.5509 / 2019924665$

\section{Introduction}

The notion of precarity, of the general condition of living and working in uncertainty and the structural conditions underpinning it, has

gained traction within political economy literature that explores the disruptive impacts of global technological change and industrial reform on

Tu Phuong Nguyen is a research fellow at the Centre for Governance and Public Policy, Griffith University, Australia. She is the author of Workplace Justice: Rights and Labour Resistance in Vietnam (Palgrave Macmillan, 2019). Email: tu.nguyen@griffith.edu.au 
the nature and meaning of work, welfare, and citizenship. ${ }^{1}$ An interest in the rise of precarious employment in advanced economies in the West has emerged with intensified market competition leading to the need for labour flexibility, and the retreat of the welfare state. Precarious employment, in this conventional sense, is typical of people working in the informal economy, the self-employed, and those working on fixed-term and casual contracts that provide limited or non-existent formal protections. In developing Asia, precarity in waged employment has been the norm rather than the exception, with low-income labourers who produce for the global markets being exposed to various forms of economic, social, and political vulnerabilities subject to the state's regulation, developmental agenda, and market fluctuations. ${ }^{2}$

This paper contributes to the scholarship on precarious labour in Asia by shifting the analytical and empirical foci from workers' vulnerabilities to sites of resilience and resistance amidst these structural changes and existential uncertainties. It will, in particular, explore the way in which state law influences workers' responses to precarity and whether and how successful they are in mitigating their precarious experience. The aim is to evaluate the opportunities and constraints the law provides in shaping workers' strategies against precarity and in delivering workplace and social justice. I note that, even though various aspects of legal rights and regulations have been discussed in previous studies of precarity, ${ }^{3}$ little attention has been paid to workers' experiences and engagements with the law on a daily basis and whether and how law interacts with other social, political, and ideological factors in shaping and/or exacerbating their precarity. This paper contributes a socially grounded discussion of law and precarity in a transitional context like Vietnam, where legal reform has been crucial to the development of a market economy and regulations of labour relationships in line with market principles. This analytical approach also complements conventional

Guy Standing, The Precariat: The New Dangerous Class (London \& New York: Bloomsbury Academic, 2011); Leah Vosko, Managing the Margins: Gender, Citizenship, and the International Regulation of Precarious Employment (New York: Oxford University Press, 2010); Arne L. Kalleberg, "Precarious Work, Insecure Workers: Employment Relations in Transition," American Sociological Review 74, no. 1 (2008): 1-22; Gabriella Alberti et al., "In, Against and Beyond Precarity: Work in Insecure Times," Work, Employment and Society 32, no. 3 (2018): 447-457; Jonathan Parry, "Precarity, Class, and the Neoliberal Subject," in Industrial Labor on the Margins of Capitalism: Precarity, Class and, the Neoliberal Subject, eds. Chris Hann and Jonathan Parry (New York \& Oxford: Berghahn, 2018), 1-38.

Teresita Cruz-Del Rosario and Jonathan Rigg, "Living in an Age of Precarity in 21st Century Asia," Journal of Contemporary Asia 49, no. 4 (2019): 517-527; Ronaldo Munck, "The Precariat: A View from the South," Third World Quarterly 34, no. 5 (2013): 747-762; Hasan Ashraf and Rebecca Prentice, "Beyond Factory Safety: Labor Unions, Militant Protest, and the Accelerated Ambitions of Bangladesh's Export Garment Industry," Dialectical Anthropology 43, no. 1 (2019): 93-107.

Irene Pang, "The Legal Construction of Precarity: Lessons from the Construction Sectors in Beijing and Delhi," Critical Sociology 45, no. 4-5 (2019): 549-564; Mimi Zou, "The Legal Construction of Hyper-Dependence and Hyper-Precarity in Migrant Work Relations," The International Journal of Comparative Labour Law and Industrial Relations 31, no. 2 (2015): 141-162; Charanpal S. Bal, "Dealing with Deportability: Deportation Laws and the Political Personhood of Temporary Migrant Workers in Singapore," Asian Journal of Law and Society 2, no. 2 (2015): 267-284. 
pluralistic understanding of law that has focused mainly on the role and experiences of legal professionals and local elites in achieving legal compliance and shaping regulatory practices in developing societies. ${ }^{4}$

Through an ethnographic account of the life and work of retired state workers in Vietnam, this paper shows that workers' experiences of precarity are shaped not just by the political economy of industrial transition but also the way in which workers experience, engage with, and even manipulate the law regulating their workplace benefits on a daily basis. The case study analysis concerns a construction enterprise in Hồ Chí Minh City. This enterprise was established and owned by the state in the early $1960 \mathrm{~s}^{5}$ and underwent some structural reform in the early 2000s. This empirical study of the state workers also adds to the existing literature of precarity in Vietnam that has focused on rural-to-urban migrants working across formal and informal economic sectors following the economic reform period. ${ }^{6}$ The construction enterprise studied here may not be representative of state enterprises in other industries, but is a typical example of those that have operated under two systems of rules and management practices during Vietnam's economic transition.

I conducted semi-structured and open-ended interviews with twenty workers who are in their late fifties or early sixties and have retired. They all used to work in this enterprise, for periods ranging from 20 to more than 30 years. I obtained preliminary information about this enterprise thanks to my contacts and conversations with key informant workers established from a previous research project concerning workers' rights and benefits in manufacturing industries. For this particular project, from July to October 2018, I used snowball sampling and indirect contacts to approach and request other workers, who had worked here for a long time and were willing to share their experiences, to participate in the interviews. Seventeen of the interviewees are male, which reflects the gendered nature of the construction industry that usually has physically demanding tasks. Most of them used to work in the production section, where tasks are often heavy and hazardous (as opposed to administrative and clerical positions), and two were transferred

4 David M. Trubek and Alvaro Santos, "Introduction: The Third Moment in Law and Development Theory and the Emergence of a New Critical Practice," in The New Law and Economic Development: A Critical Appraisal, eds. David M. Trubek and Alvaro Santos (Cambridge: Cambridge University Press, 2006), 1-18; Boaventura de Sousa Santos and César A. Rodríguez-Garavito, "Law, Politics, and the Subaltern in Counter-Hegemonic Globalization," in Law and Globalization from Below: Towards a Cosmopolitan Legality, eds. Boaventura de Sousa Santos and César A. Rodríguez-Garavito (Cambridge: Cambridge University Press, 2005), 1-26.

According to a 2002 survey by the General Statistics Office, manufacturing, trade, and construction are the three industries with the highest numbers of state-owned enterprises. See Martin Painter, "The Politics of Economic Restructuring in Vietnam: The Case of State-owned Enterprise Reform," Contemporary Southeast Asia 25, no. 1 (2003): 20-43, 26.

6 Dennis Arnold, "Social Margins and Precarious Work in Vietnam," American Behavioral Scientist 57, no. 4 (2013): 468-487; Minh T.N. Nguyen, "In a "Half-dark, Half-light Zone": Mobility, Precarity and Moral Ambiguity in Vietnam's Urban Waste Economy," Trans-Regional and-National Studies of Southeast Asia 7, no. 1 (2019): 43-61. 
to security a few years before their retirement. All interviews were conducted at the workers' homes. I also had conversations with the wives and children of four of these workers to learn more about their families' health care and living arrangements. These conversations allowed me to immerse further in the stories of these pensioners and their families and appreciate their efforts to cope with conditions that they perceive to be difficult, uncertain, and unjust.

The paper proceeds with a brief discussion of precarious labour in Asia and the conceptual and analytical approaches of my research. It then outlines key reforms in labour relations and social insurance in Vietnam, which is necessary for understanding state workers' rights and entitlements. The case study discussion delves into workers' workplace experiences, their collective and individual struggles for decency and fairness, and the interplay between the legal, social, and political factors underpinning their struggles.

\section{Precarious Labour in Asia}

An understanding of the growth of precarious labour in industrialized Asia, first of all, has to be situated within the state's broader economic developmental agenda. ${ }^{7}$ In their integration into the global economy, these developing economies have widely adopted the export-oriented growth model and capitalized on their natural resources and low-cost labour to attract private, and mostly foreign investment. Labouring in exhausting and exploitative conditions, manual assembly workers producing for global markets are exposed to various forms of vulnerabilities-economic, social, legal, or political-as they struggle to earn a decent and dignified living. Even work that seems to guarantee formal social and legal protection is not immune to external shocks, forcing businesses to cut costs and restructure their labour force, or to threaten discipline and retaliation when demands for better wages and working conditions are raised. Furthermore, the capacity of labour to organize, especially in authoritarian contexts, is limited and curtailed as state-capital alliances are consolidated in pursuit of the neoliberal developmental agenda. ${ }^{8}$ Studies of precarious work in Asia, and more broadly, the developing world, have therefore captured a broad range of social and political processes that produce different experiences of precarity and contribute to making employment and welfare less stable or secure, rather

$7 \quad$ Teresita Cruz-Del Rosario and Jonathan Rigg, "Living in an Age of Precarity in 21st Century Asia,” Journal of Contemporary Asia 49 no. 4 (2019): 517-527; Arne L. Kalleberg and Kevin Hewison, "Precarious Work and the Challenge for Asia," American Behavioral Scientist 57, no. 3 (2013): 271-288.

$8 \quad$ Ching Kwan Lee and Yelizavetta Kofman, "The Politics of Precarity: Views Beyond the United States," Work and Occupations 39, no. 4 (2012): 388-408; Alice Evans, "Patriarchal Unions = Weaker Unions? Industrial Relations in the Asian Garment Industry," Third World Quarterly 38, no. 7 (2017): 1619-1638. 
than adopting a class-based account of non-standard working status as a prerequisite for a discussion of precarity. ${ }^{9}$

The political economy of development in Asia thus requires an analytical approach that focuses on the social and political dynamics shaping workers' subjectivity and resistance to precarity. Writing about the case of China, Ching Kwan Lee argues for a conceptual view of precarity as "relational struggles," 10 that is, as conditions that vary amongst nations and contexts, and more importantly, as dynamics of ongoing interactions and contestation between labour, capital, and the state in the changing political economy landscape. These struggles crosscut various aspects of workers' ideological, moral, and legal stances, their subsistence and care obligations on a daily basis, and the passage and implementation of laws and policies regulating labour-capital relationships. Throughout her historical analysis of labour struggles in China, Lee has demonstrated how workers in different situations, including those employed in the state sectors, internal migrant workers engaged in waged work, and those working in the informal economy, became subordinated to the state's developmental agenda and its alliance with capitalist interests, while managing to engage and negotiate with the state and its formal institutions to fight for better rights and entitlements. This framework also captures the often neglected daily individual actions against precarious conditions, whereby workers turn to their social networks or employ self-help measures to overcome their situations.

This paper employs and builds upon Lee's conceptual framework by focusing on workers' struggles within the regulatory space and how their agency and/or subjectivity play out in this space. Further analysis will hone in on the law as one of the key regulatory factors, and one that is analytically important for its institutionalization of rights, benefits, and obligations of parties involved in the labour relationships. Following the sociological approach to the study of law, ${ }^{11}$ this paper uses the term "law" as a shorthand to refer to key legislations, values, and understandings derived from state law, and commonplace practices associated with law compliance and

9 Matthew Alford, Stephanie Barrientos, and Margareet Visser, "Multi-Scalar Labour Agency in Global Production Networks: Contestation and Crisis in the South African Fruit Sector," Development and Change 48, no. 4 (2017): 721-745.

10 Ching Kwan Lee, “China's Precariats," Globalizations 16, no. 2 (2019): 137-154, 137.

11 This approach explores whether and how law, amongst other modes of normative schemas and orderings, influences social meaning, behaviour, and approach to social disputes. Everyday acts and expressions thus become important empirical sites through which to explore the power and legitimacy of the law. Whether and how people use or engage with the law in solving everyday problems also depends on, for instance, their class status, legal knowledge, perceptions of state authority, and prior legal experiences. See, for instance, Patricia Ewick and Susan Silbey, The Common Place of Law: Stories from Everyday Life (Chicago and London: The University of Chicago Press, 1998); Austin Sarat, “...The Law is All Over: Power, Resistance and the Legal Consciousness of the Welfare Poor," Yale Journal of Law and the Humanities 2, no. 2 (1990): 343-379; Laura Beth Nielsen, "Situating Legal Consciousness: Experiences and Attitudes of Ordinary Citizens about Law and Street Harassment," Law E Society Review 34, no. 4 (2000): 1055-1090. 
enforcement. The case study analysis will tease out how these values, understandings, and practices of law constitute or exacerbate workers' struggles and the implications for the delivery of workplace and social justice.

\section{Social Insurance Reform in Vietnam}

This section outlines key changes concerning social insurance policy in Vietnam as part of the shift from socialist to market labour institutions. During the socialist era, the labour relationship was established on the basis of the socialist social contract, which guaranteed life-long income and welfare for workers in exchange for their loyalty to the state and state-owned enterprises. Since Vietnam shifted from a central planning system to a market-based economy following đổi mói (renovation) in 1986, work and remuneration have been regulated by legal contracts and subject to market forces. Despite endorsing private investment and market mechanisms, the leadership of the Communist Party of Vietnam (CPV) still holds on to its socialist ideology and proclaims itself as the genuine political representative of the working class. Since the 1990s, the state has introduced and revamped key labour legislation designed to promote workers' rights and to "look after [their] material and mental lives." 12 The government has implemented an annual wage increase for employees in the state and private sectors since 2007. ${ }^{13}$ Employees' basic wages, which must be at least equal to the government-issued minimum wage, determine their entitlements to the compulsory and contributory social insurance scheme which covers old-age pension and other work-related benefits.

During the socialist era, social insurance benefits were defined based on the minimum level of subsistence and the reciprocal obligations between employees and the state or state-owned enterprises. In particular, retirement benefits were determined by workers' contributions (sư cống hiến), years of service, working conditions, and the level of loss in their working capacity. ${ }^{14}$ The retirement ages were 60 for males and 55 for females. Employees could retire early and access their pension benefits when (1) they had worked for 25 years for men or 20 years for women, providing that there was five years of continuous work, or (2) when they were in poor health and no longer able to work, after at least 15 years of continuous service. The pension

12 The Central Committee of the Communist Party of Vietnam, Directive 20/NQ-TW (2018) on continuing to develop the Vietnamese working class in the modernization and industrialization era (Ha Noi, 28 January 2018).

13 There are separate provisions for employees in the state and private sectors. For a more comprehensive discussion of wage regulation in Vietnam, see Angie N. Trần, Ties that Bind: Cultural Identity, Class, and Law in Vietnam's Labor Resistance (Ithaca: Cornell Southeast Asia Program Publications, 2013).

14 The Government Council of the Democratic Republic of Vietnam, Decree 218-CP on temporary regulations of social insurance entitlements for state workers and officials (Ha Noi, 21 February 1961), Article 2. 
allowance in general would be lower than the normal wage, but the lowest amount had to be equal to the minimum living standard. ${ }^{15}$ The calculation of allowance also placed emphasis on the loyalty of workers' service to the state and its enterprises. In particular, when a worker's continuous length of work was greater than five years, from the sixth year onwards, the pension rate would increase by 1 percent for each year, and from the eleventh year onwards, the pension rate would increase by 2 percent. ${ }^{16}$

A new social insurance scheme was experimented with throughout the 1990s and institutionalized in 2006 with the introduction of the Law on Social Insurance. It is one of the key labour legislations whose amendments and implementation in relation to workers' rights and welfare have attracted much attention from the state and public in recent years. Social insurance is defined by law as "an alternative guarantee or partial compensation for employees' income when their income is reduced or lost due to illness, maternity, occupational accidents and illness, unemployment, retirement or death, based on the contribution to the social insurance fund." ${ }^{17}$ Employers and employees are obligated to contribute a certain amount of money to employees' insurance premiums, which include social insurance, health insurance, unemployment insurance, and insurance of occupational diseases and accidents. Social insurance, which is the largest component of insurance premiums, is mainly to cover for pension and maternity benefits. The rates of contribution from employers and employees have been adjusted over the years; as of 2018, they sit at 17 percent from employers and 8 percent from employees. Employees who have contributed to the social insurance scheme for at least 20 years are entitled to a monthly living allowance when they retire. Similar to the pre-reform policy, the living allowance is based on employees' duration of work and their basic wage during employment. It is stipulated that the minimum pension must be equal to the common minimum wage,$^{18}$ which is the wage rate applied to state employees and officials. Employees who wish to retire early and obtain their pension, provided they have contributed to the social insurance scheme for at least 20 years, have to prove that their working capacity has decreased at a rate of 61 percent by going through a health check conducted by the state medical agency.

Some of the significant changes to social insurance policy, starting from the early 1990s, are worth highlighting. The first change is the abolition of the condition regarding "continuing duration of work" in determining

15 Government Council of the Democratic Republic of Vietnam, Decree 218-CP on temporary regulations.

16 Article 46, Decree 218-CP.

17 National Assembly of Vietnam, Law on Social Insurance (Ha Noi, 20 November 2014), Article 3.1 .

18 Article 52.3, Law on Social Insurance. 
employees' eligibility for early retirement and pension. ${ }^{19}$ The policy in the socialist era considered employees' continuing service as part of the conditions for early retirement while the new policy stipulates only one condition: their physical capability to work has declined. Now, the pension allowance is calculated based on the number of years worked, regardless of continuing service. The benefit to an employee for remaining loyal to the same employer for their whole working life is no longer there. Another change is the shift from the "minimum living standard" towards the "common minimum wage" in the stipulation of the minimum pension. The common minimum wage in 2018 was 1,390,000 dong (approximately \$60 US) per month, ${ }^{20}$ which is far below the standard minimum living needs. In brief, while social insurance benefits are still in principle contingent on employees' duration of employment and the wage levels that they are paid, the incentive for continuous employment with a guarantee of funding retirees' livelihood, as found in the socialist era and valourizing the moral values of a liveable income and ethical obligations of the state and state enterprises in exchange for workers' loyalty, no longer holds in the post-reform era.

In 2017, several news reports about the meagre and insufficient pension of kindergarten teachers in a few northern provinces stimulated public debate concerning the benefits of the social insurance system. Such debate differs from the dominant discourse in the mainstream media and policy and academic community in Vietnam, which has mainly concentrated on the challenges of social insurance coverage and the sustainability of the social insurance fund for an aging population. ${ }^{21}$ At the centre of the debate were the teachers, who had worked for more than 30 years only to receive 1.3 million dong per month when they retired..$^{22}$ The newspapers contrasted

19 Starting from Government Decree 43-CP on temporary regulations of social insurance entitlements (Ha Noi, 22 June 1993).

20 Regarding employees in the public sector who are still at work, their wages are calculated by multiplying the base line (the common minimum wage) with a pay rate depending on their qualifications and ranks.

21 Giang Thanh Long, "Hệ thống hưu trí Việt Nam: Hiện trạng và những thách thức trong điều kiện dân số già hóa," [Pension System in Vietnam: Current Situation and Challenges under Condition of Aging Population] Diễn đàn Phát triển Việt Nam (2004), accessed 23 August 2019, http://www3. grips.ac.jp/ 21coe/share_docs/VDFDP2V.pdf; Nguyễn Hữu Dũng, "Hệ thống chính sách an sinh xã hội ở Việt Nam: Thực trạng và định hướng phát triển," [Social Security Policies and System in Vietnam: Current Situation and Directions for Development], Tạp chí Khoa hoc ĐHQGHN, Kinh tế và Kinh doanh 26 (2010): 118-128; Tuổi Trẻ, Thục hiện cân bằng quỹ bảo hiểm xã hội [Implementation to Balance Social Insurance Fund], 14 May 2014, accessed 23 August 2019, https://tuoitre.vn/thuc-hien-canbang-quy-bao-hiem-xa-hoi-607239.htm.

${ }_{22}$ Lao Động [The Labour], Vi sao hiơng hưu đối với giáo viên mà̀m non thấp? [Why Are Kindergarten Teachers' Pensions Low?], 2 November 2017, accessed 20 December 2018, https:/ /laodong.vn/congdoan/vi-sao-luong-huu-doi-voi-giao-vien-mam-non-thap-573564.ldo; Người Lao Động [ The Labourer], Cám cảnh huơng hư giáo viên! [Pity for Teachers' Pension!], 6 November 2017, accessed 20 December 2018, https://nld.com.vn/thoi-su/cam-canh-luong-huu-giao-vien-20171105212007237.htm; Người Lao Động, Đại biểu QH lên tiếng về cô giáo nhận kiơng huru 1,3 triệu đồng [Delegates of the National Assembly Raised Their Voices about the Kindergarten Teachers' Pension of 1.3 Million Dong], 31 October 2017, accessed 20 December 2018, https://nld.com.vn/thoi-su/dai-bieu-qh-len-tieng-ve-cogiao-nhan-luong-huu-13-trieu-dong-20171031173424098.htm. 
their length of contribution (sụ cống hiến), which was a part of the socialist discourse, with them receiving such a small old-age allowance that it barely met half of the pensioners' minimum living needs. The common minimum wage, serving as a legal basis for the pension, in reality failed to provide for the pensioners' subsistence. There was moral outrage in the media about these retired teachers' poverty and the fact that they have had to take on petty work to survive. State officials in charge of the implementation of social insurance law were quick to respond to this media coverage, suggesting that the teachers' pension is low due to a disjuncture in the remuneration of their service and their low wage while at work. Such response is a justification of the persistence of poverty amongst elderly people and contradicts the state's socialist propaganda of promoting social insurance law to improve the social welfare of the working people.

\section{State Workers' Working Experiences Following Đổi Mới}

The construction enterprise examined in this case study was established in the early 1960s and was amongst the top producers of slated roofs for local and international markets. It underwent equitization and became a jointstock company in the early 2000s. Equitization, or partial privatization, of state-owned enterprises is a key pillar of the economic reform agenda that started in the early 1990s in Vietnam. Following equitization, the ownership of former state enterprises is now shared between the state and private capital..$^{23}$

Reform to the labour relationships in line with market principles put workers' benefits and working conditions in the hands of private management. As suggested by the retired workers, their income and benefits have been reduced compared to the pre-equitization period. Workers complained that the Tết and other holiday bonuses ${ }^{24}$ were significantly lower or cut, and their income, paid by the piece rate, was just enough to cover their living expenses amid rising inflation. Their income used to range from 3.8 to more than 6 million dong (approximately $\$ 160$ to $\$ 250$ ) a month. Their basic wage, which is used to calculate social insurance benefits and subsequently their pension, remained stagnant for more than ten years after the enterprise's restructuring. These eroded benefits left the state workers economically worse off while the cost of living rose. This is not to mention that their workload increased, as the company cut down on the workforce in each production group by between a half and a third without proportionally reducing the assigned tasks for the remaining workers. Workers contrasted their working conditions

23 Martin Gainsborough, "Privatisation as State Advance: Private Indirect Government in Vietnam," New Political Economy 14, no. 2 (2009): 257-274.

24 For an overview of workers' non-wage benefits in the socialist era see Tuong Vu, "Workers and the Socialist State: North Vietnam's State-Labor Relations, 1945-1970," Communist and PostCommunist Studies 38, no. 3 (2005): 329-356. 
and earnings after reform with their situation when the enterprise was stateowned: a "small, but liveable income," a more relaxed working environment, and other benefits and bonuses.

This condition of declining economic security is further exacerbated by an acute feeling of injustice when their contribution to the business over the years has failed to be fairly reciprocated or remunerated. The interviewed workers saw their work for the state as privileged compared with their experience of being treated as a mere commodity subject to exploitation and mistreatment in the post-reform era. In our conversations, these former workers bitterly recalled their dedicated continuing service to the business through good and bad times, including month-long periods of work suspension when they were paid a small fraction of their usual income. More than half of them worked for the same company from their twenties until retirement, while the others shifted between formal and casual jobs. Those who switched jobs had still worked for this company for at least twenty years. Their experiences of precarity have unfolded in their everyday struggle to survive and to work with decency in the face of unfair managerial treatment.

There are other factors relating to business and the union's performance that exacerbated workers' dissatisfactions and in turn led to their decisions to retire early. Some of them said that the business no longer functioned as well as it used to, especially when the management only "held meetings and dined" ( $\breve{n}$ rồi hop $p$ ), and when business profits seemed to decline. Some were worried that, in the worst-case scenario, the business might be dismantled or go bankrupt, with workers likely to lose all their legal rights and benefits. Such pessimistic projections were based on their view that the state authority and company union had failed to act on workers' behalf while the business continued its problematic wage payments and coercive practices (with more details forthcoming in the next section). These revelations resonate with findings from another study ${ }^{25}$ which identifies satisfaction at work, leadership behaviour, workplace relationships, and wage and benefits as key reasons for Vietnamese state employees' intentions to resign. These state workers also did not consider the option of finding a new formal job as they knew that the labour market in the manufacturing industries prefers young job seekers, assuming that they have greater strength and productivity. ${ }^{26}$

25 The findings are based on a quantitative analysis of 277 surveys with Vietnamese state employees. Võ Quốc Hưng and Cao Hào Thi, "Các yếu tố ảnh hưởng đến dự định nghỉ việc của công chức - viên chức nhà nước," [Factors Affecting Planned Resignation of State Employees and Officials], Tạp chí phát triển KHEF CN 13, no. 1 (2010): 5-16.

26 Người Lao Động, Lao động lớn tuổi: đằng sau họ là gánh nặng gia đình [Older Workers Shoulder the Burden of Their Families], 5 June 2017, accessed 20 December 2018, https://nld.com.vn/congdoan/lao-dong-lon-tuoi-dang-sau-ho-la-ganh-nang-gia-dinh-20170605152447917.htm. 


\section{Responses to Precarity}

Workers' responses to precarity manifest in collective and individual actions, take place during and after the time they worked, and involve engagements with parties and actors within and outside the formal employment relationships. As recalled by the workers interviewed, there had been a few small factory strikes in which workers demanded a wage increase, but none of them succeeded due to the management's failure to negotiate with the workers or meet their demands. Unsurprisingly, the enterprise union only existed in a cosmetic manner and failed to stand up for workers' rights and interests. ${ }^{27}$ The harsh working conditions and unfair wages and treatment led many workers to quit their jobs. In 2015, a relatively young worker used his knowledge about the labour law to mobilize support from 14 other workers in the same production unit. Together they signed and lodged a complaint letter to the company management and the district-level labour bureau in charge of law enforcement and monitoring. This action triggered the labour bureau's perfunctory gesture to investigate the problem. A few months later, the management held individual meetings with the workers who signed their names on the complaint letters. In his exchange with the management, one of the workers raised an issue: "With such wage and social insurance benefits, how would we subsist when we retire?" 28 The workers' collective attempt to demand justice did not sustain its momentum, as the management made individual promises to the workers that a wage rise would be considered in the new year. The manager also put further pressure on the young worker who initiated the complaint process and ultimately dismissed him on the grounds of disciplinary measures.

As workers' disappointment about their wages and benefits continued to grow, these state workers opted to quit and claim their old-age benefits before they reached the legal retirement age. One of the workers, Hai, told me how he came to such a decision:

I started working in the factory at the age of 22. I have worked here for a few decades, and until a few years before the retirement age, I thought that I could try working a bit longer to get the pension booklet. But I couldn't try any longer. How could I live with 3.8 million dong a month? ${ }^{29}$

27 According to the workers, the union in this company is filled by people in human resources or managerial positions. This is similar to the situation in most other enterprise unions in Vietnam. In the broader context, Vietnam only allows one legal trade union affiliated with the Communist Party of Vietnam, the Vietnam General Confederation of Labour. It has branches across the local administrative level, filled by state officials and employees. The union established at the enterprise level is affiliated with these local branches.

28 All interviews were conducted in confidentiality, and the names of interviewees are withheld by mutual agreement. Interview \#2, Ho Chi Minh City (HCMC), 18 September 2018.

29 Interview \#6, HCMC, 25 September 2018. 
As required by law, employees who wish to retire early have to go through a health check conducted by the state's local medical agency, to prove that they have lost their capacity to work. If these employees obtain a result with a rate of 61 percent, they are able to retire early and receive a monthly pension. The rate is determined by a medical examination board (hộ i tồng giám dịnh y khoa), made up of a group of qualified doctors who are responsible for the diagnosis and examination of employees' health conditions. When applying for the health check, employees can also submit their previous health record detailing any illness, diagnosis, and hospitalization. The eligible age for consideration of early retirement is 45 for women and 50 for men. ${ }^{30}$

The process of a pre-retirement health check, in reality, is prone to brokerage and corruption. The Labourer, one of the largest labour newspapers in Vietnam, reported about the "lubrication" of health checks for early retirement. ${ }^{31}$ Writing about the situation in Hà Nội, the reporter revealed the case of a broker who acted as an intermediary between prospective retirees and doctors. In Vietnam, the word "broker" (cò) carries a negative connotation, referring to people taking advantage of ordinary citizens' urgent and immediate needs to earn money. After receiving payment from prospective retirees, the broker ensured that the doctors gave an "unfavourable" assessment of the examined worker's health condition in such a way that met the worker's intention to retire. The deals between the broker and prospective retirees took place right in front of the medical agency responsible for the pre-retirement health check. This report later prompted investigation by the state authority and eventually disciplinary measures against the doctors and instalment of camera surveillance at the medical agency.

The pensioners in my case study went through a process that took place in a private space, which makes it less susceptible to state surveillance. Tùng, for instance, sought help from one of his acquaintances, who had also arranged for the health check through a broker and obtained a satisfactory result. This acquaintance confided in Tùng the amount of money it would cost to get through, and accompanied him to meet the female broker at her home who then facilitated his test:

She [the broker] lives close to the doctor's home. She took note of my name and the date and time of my medical appointment. She then called the doctor in advance mentioning my name and the time of my appointment or so. When I went to the test, the doctor knew my name

30 Recent amendments to the Law on Social Insurance have increased the eligibility ages of early retirement by one year for both sexes.

31 Người Lao Động, Sụt thật "bôi trơn" giám định để về hiu non [The Truth about the "Lubrication" of the Health Check for Early Retirement], 16 April 2017, accessed 20 December 2018, https://nld. com.vn/an-ninh-trat-tu/su-that-boi-tron-giam-dinh-de-ve-huu-non-20170416091713779.htm. 
so he increased the severity of my illness for me. When I had my back checked and had the X-ray test and there were only me and the doctor in the consultation room, I "injected" the doctor another 300,000 dong. ${ }^{32}$

Tùng's money "injection" is an example of the rampant bribery in the public health system in Vietnam, where patients are obliged to line the pockets of their doctors and nurses if they wish to receive good care and treatment. Overall, the pensioners had to spend more than 8 million dong for this process, which is worth approximately two times the monthly income that they received. This practice, which workers colloquially referred to as "bao đậu" (guaranteed pass), can also be found in other services that assist people, from driver's licenses to foreign language tests and entrance exams. The broker similarly exploits the service users' wish to get things done promptly and easily by charging a good deal of service costs. Since the result of the health check is almost guaranteed, the cost that doctors and brokers charge for the health check is often not open to negotiation. Those needing an exemption based on health either accepted the amount asked for by the brokers, or even offered more incentives along the way, when they felt that "things were not so smooth" (thấy không êm). Despite the bribes, two of the pensioners still "failed" the first health check, but were able to have the second check conducted in a month's time, rather than six months as stipulated by law. They managed to gain more "percentage points" following diagnoses of more serious medical problems in the second test. In referring to the result as "points" (điểm), these workers were "monetizing the grade" 33 required by law to access their pension benefits.

The state workers managed to obtain their monthly pension, ranging from 1.6 million to 2.8 million dong ( $\$ 68$ to $\$ 120)$ a month. The pension is calculated based on workers' (low) basic wages they received while at work and their early retirement. According to the law, each year of early retirement was penalized by a deduction of 2 percent from the monthly pension rate. For instance, a male worker whose monthly pension rate is determined at 70 percent of his average basic wage, but who retires at 57 years of age (three years earlier than the legal retirement age), will have the rate reduced to 64 percent. Legal reform therefore institutionalizes workers' subjectivity to new rules that depart from the moral principles of subsistence and in turn contribute to their precarious living. While the living needs of an individual and their household is relative, we can still get a sense of how high or low the above figures are by comparing them with the government-issued minimum living wage, classified into four categories for four regions based on their living costs. The amount designated for key urban areas including Hồ Chí Minh City was 2.7 million and 3.1 million in 2014 and 2015,

32 Interview \#18, HCMC, 8 October 2018.

33 Daniel J. Smith, A Culture of Corruption: Everyday Deception and Popular Discontent in Nigeria (Princeton: Princeton University Press, 2007), 74. 
respectively, the years that most interviewed workers retired. As stipulated in the Labour Code, ${ }^{34}$ a minimum wage must meet the minimum living needs of employees and their families. In reality, the government's annually adjusted minimum wage has fallen short of this provision, estimated to satisfy only 70 to 80 percent of employees' minimum living needs. ${ }^{35}$ The pension allowance of most state workers is clearly below this minimum wage level.

Besides the monthly pension allowance, these former state workers are also entitled to the state's medical insurance, which gives them free or discounted treatment at public hospitals. However, the accessibility of public health services in Vietnam does not guarantee good quality treatment and the extra cost needed for good service can be a financial burden to lowincome citizens. ${ }^{36}$ Eight interviewed pensioners said they had to shoulder an extra financial burden from medical expenses as they suffered from occupational diseases and injuries after many years of hard and hazardous work. Added to this is the general declining health and physical capacity as workers age. Huy, for instance, who once suffered from a stroke, resorted to private health treatment after his health condition failed to improve despite ongoing treatment at the public hospital. The failure of the public health system to deliver good quality health care meant that the pensioners in my study had to pay extra for private medical expenses.

Struggling to survive on a substandard allowance, retirees in my study who have managed to stay fit and healthy have been working casually, or take on petty trade activities to supplement their pension. In Vietnam, while adult children are expected to take care of their elderly parents according to filial piety practices, most retirees prefer not to financially depend on their adult children. Most retirees interviewed for the study have their own houses, while a few are still renting or living with their spouses' family. Half of the retired workers work as security guards in business compounds or residential areas without any labour contract. Their shifts span twelve hours, either during the day or at night. These workers have benefitted from the growth of the labour dispatch system, whereby "an enterprise licensed to operate as a labour dispatch enterprise recruits an employee to work for another employer. The employee works under the control of the latter employer, while maintaining a labour relationship with the dispatch enterprise." ${ }^{37}$ In reality, there have been cases in which the dispatch enterprise fails to register

34 National Assembly of Vietnam, Labour Code (Ha Noi, 18 June 2012), Article 91.

35 Lao Động, Chủ tịch Tổng LĐLĐVN Đặng Ngọc Tùng: Lương tối thiểu vùng I năm 2015 cần đạt 3,4 triệu đồng/người/tháng [The Chairman of the Vietnam General Confederation of Labour Dang Ngoc Tung: Minimum Wage for Region I in 2015 Needs to Reach 3.4 Million Dong per Person a Month], 31 July 2014, accessed 20 December 2018, http:/ / laodong.com.vn/cong-doan/chu-tich-tongldldvn-dang-ngoc-tung-luong-toi-thieu-vung-i-nam-2015-can-dat-34-trieu-dongnguoithang-229651.bld.

36 Ly Chu, "The Quest for Research on Social Class in Contemporary Vietnam," Journal of Vietnamese Studies 13, no. 1 (2018): 42-79, 61.

37 Article 53, Labour Code. 
with the state authority or to sign a labour contract with the workers,$^{38}$ which in turn jeopardizes workers' rights and their employment security. Another pensioner and his wife managed to invest in a small shop from their own savings and the lump sum from social insurance that his wife obtained after quitting her job. Their work after retirement is similar to the reported experiences of state workers in Hà Nội in the 1990s,${ }^{39}$ who also took extra informal work to supplement their pension. Yet while most of the state workers in Hà Nội spoke positively about their retirement life and welfare, after having suffered from severe food shortages during the time they worked, the workers in this study expressed feelings of grief and disappointment about their livelihood after retirement.

\section{Precarity as an Ideological Struggle}

In the previous section I detailed three instances of workers' responses to precarity in my case study: their strikes and petitioning while at work in protest of declining economic security and job dissatisfaction, their early retirement, and their survival strategies in their old age. The precarity that they have experienced is not just concerned with aging and the attendant decline in their well-being, economic opportunities, and social security, ${ }^{40}$ but also with the changes to managerial and ideological systems governing their work and life. This section will explain and flesh out the social, ideological, and legal factors that shape and/or reproduce workers' struggles against precarity in the company under study. First of all, workers' strikes and petitioning reveal the gap between workers' expectations of workplace benefits and managerial treatment following equitization, and what they in fact received. Such expectations, which centre upon workers' minimum living needs and fair treatment in exchange for their loyalty to the business, echo values, principles, and practices of subsistence and reciprocity grounded in the socialist labour institutions. While workers' strikes were spontaneous, not organized by the union and bypassed the legal procedure of strikes, their collective petitioning involved interactions with an authority in charge of law monitoring and enforcement. The failure of the labour authority to respond to workers' voices while the business continued its arbitrary

38 Author's conversations with workers, HCMC, September-October 2018.

39 Melinda T. Kerkvliet and Le V. Sinh, "Life Stories of Retired Factory Workers in Hanoi," paper presented at the Bi-Annual EUROVIET Conference III, Amsterdam, 1997.

40 Some scholars have recently applied the notion of precarity in studying elderly people's welfare and security, with most discussion viewing precarity as outcomes and manifestations of social inequality. See Rachel Barken, “'Old Age' as a Social Location: Theorizing Institutional Processes, Cultural Expectations, and Interactional Practices,” Sociology Compass 13 (2019): 1-14; Val Colic-Peisker, Rachel Ong, and Gavin Wood, "Asset Poverty, Precarious Housing and Ontological Security in Older Age: An Australian Case Study," International Journal of Housing Policy 15, no. 2 (2015): 167-186; Chris Gilleard and Paul Higgs, "Precarity and the Assumption of Rising Insecurity in Later Life: A Critique," Ageing E Society (2019): 1-18. 
treatment exacerbates their sense of precarity, leading them to resort to self-help measures in a hope to improve their conditions.

The state workers' second response to precarity is more complex and has to be understood in light of how they perceive and aspire to obtain their pension benefits. In their conversations with me, the workers made it clear that the pension benefits, which include living allowance and free medical insurance to be enjoyed until death, were meaningful to them, not just in an economic but also symbolic sense. The free medical insurance issued by the state ${ }^{41}$ is especially crucial for workers suffering from long-term illnesses, either caused or worsened by their exposure to hard and hazardous working conditions. The insurance would allow them to receive ongoing medical treatment without much financial stress. Symbolically, the pension benefits are a testimony of workers' decades-long employment, dedication, and loyalty to the enterprise, something they perceived as morally deserving and rewarding. As Angie Trần has noted, despite bidding farewell to the guaranteed economic and social welfare that they enjoyed during the socialist era, state workers in Vietnam still "[carry] the socialist ideology with them, into the workplace, along with their expectations that the socialist contract would be honoured." ${ }^{42}$ To the state workers, the pension is not just a legal but a socialist entitlement, and is crucial for them to overcome feelings of insecurity and anxiety about their future livelihood.

Workers' early access to their retirement benefits is obtained through an informal measure that exists in the grey area of the law. While early access shall be granted when workers are able to demonstrate 61 percent of working capacity decrease, there is no clear specification within the law nor any policy associated with it regarding how to determine this rate. It means that the result of the health check is entirely subject to the discretion of doctors who form part of the medical examination board. This ill-defined area within the law and a network of informal brokerage are instrumental in workers' pursuit of their needs, yet they are not necessarily what workers perceive as morally right and acceptable.

The state workers' use and manipulation of the law are similar to the kind of informal practices often found amongst ordinary citizens in postcommunist and authoritarian societies. In these societies, people tend to evade or bypass the law in solving problems, most often by engaging in corruption or making use of their social networks. Such use reflects the ongoing influence of longstanding social practices that predate the advent of state laws following economic reform, as well as individuals' views of the law as corrupt, arbitrary, and distant from their daily lives. ${ }^{43}$ The citizens,

41 Medical insurance is also available to any employee working with a labour contract, yet such insurance is contributed to by a small deduction from the employees' basic wage.

42 Trần, Ties that Bind, 179.

43 Marina Kurkchiyan, "The Illegitimacy of Law in Post-Soviet Societies," in Law and Informal Practices: The Post-Communist Experience, eds. Denis J. Galligan and Marina Kurkchiyan (New York: 
nonetheless, do not necessarily consider informal, corrupt practices as morally legitimate or representative of broader social values. To the pensioners in this case study, corruption in the medical profession-despite its necessity for their purposes-is immoral and unjust, when doctors and their intermediaries make money out of the needs of workers. As Kirsten Endres suggests, "the line that distinguishes 'legitimate' corruption for a mutual 'benefit' from morally condemnable corruption for personal enrichment is a thin one." ${ }^{4}$ One pensioner in particular expressed his frustration with the whole public health-care system, one that is lacking in quality but charges patients unaffordable rates. These individualized bribery acts thus embody wider discontents and frustration with law and social justice. The socialist rhetoric and obligation of care, as widely promulgated in state propaganda and policy towards citizens and the working class, is now debased by a system that is open to corruption, disadvantaging the workers it was supposed to support and protect both economically and morally.

The third aspect of workers' struggle against precarity involves their engagement in informal economic activities and those that provide no formal labour protection. Their everyday struggle to survive in their old age underlines complex ideological issues beyond fulfilment of economic needs, which can be gleaned again from their judgements of the pension benefits. The pension benefits that these former state workers receive fall short of their expectations, which are underpinned by perceptions of their past contribution and reciprocal obligations from the business, and their subsistence needs. These expectations resonate with the ideological foundations embedded within workplace relationships and social insurance regulations in the socialist era. To illustrate, pensioners are acutely aware of the disparity between their whole loyal working life and the meagre pension that they now receive. Hai expressed his disappointment: "I started working in the factory at the age of 22. ... It's too bad that I have worked for more than three decades and received only 2.3 million dong at the time I quit." 45 Another pensioner commented that his physical deterioration due to longterm exposure to hard and heavy work should have earned him a higher compensation when he retired.

The pensioners then related the benefits received to their daily needs. One pensioner who lived in a rented house lamented that " $[\mathrm{a}]$ liveable pension now should be 5 million dong, given the cost of living. And that's

Oxford University Press, 2003), 25-46; Kathryn Hendley, "Varieties of Legal Dualism: Making Sense of the Role of Law in Contemporary Russia," Wisconsin International Law Journal 29, no. 2 (2011): 233-262.

${ }_{44}$ Kirsten W. Endres, "Making the Marketplace: Traders, Cadres, and Bureaucratic Documents in Lào Cai City," in Traders in Motion: Identities and Contestations in the Vietnamese Marketplace, eds. Kirsten W. Endres and Ann M. Leshkowich (Ithaca: Cornell University Press, Southeast Asia Program Publications, 2018), 37 (quotation marks in original).

45 Interview \#18, HCMC, 8 October 2018. 
just to care for myself. I have to go to the doctor once every month." ${ }^{46}$ This account from Văn, who was left with a disabled arm after many years of heavy work, is perhaps the most illustrative of workers' economic hardship and their self-help strategies:

\begin{abstract}
My left arm's muscle has shrunk for a long time but I still managed to do some heavy work. But on that day when I worked during the night shift, I caught a cold and was hospitalized. At that time my arm was really weak. After I quit the job and was discharged from the hospital, I took the pills and went to the physio clinic every day. The therapy costs me 35,000 dong each day, which totals around 1 million dong per month. With a pension allowance of 2.2 million dong, how could I subsist? I'd rather practise at home to save money. ${ }^{47}$
\end{abstract}

The meagre increase in the pension allowance every one or two years apparently fails to remedy workers' impoverishment. These pensioners have little to gain from the rate of 5 percent increase in their pension due to the cost of living. While inflation in Vietnam has stabilized at the rate of 3 to 4 percent since $2014,{ }^{48}$ its impact on pensioners' everyday lives is acute as they find their physical well-being deteriorating.

Apart from blaming the business for its failure to ensure their legal rights at work, which in turn affects their life after retirement, pensioners also held the state accountable for their plight. The decision letter on their pension benefits was issued by the social insurance agency at the local level and details workers' pension benefits. It outlines workers' years of service, their wage level, the average wage used for calculation of the pension amount, and any deduction due to early retirement. The letters show that, years after equitization, the management still continued to apply a wage level for state enterprises and public sectors, rather than the higher one applicable to non-state sectors. ${ }^{49}$ As the pensioners showed the decision letters to me, they complained how the state had failed to look into the legal compliance of the business for many years, and suggested that it is the state's responsibility to "care" (lo, or chăm lo) for state workers in their old age, given their length of service and contribution. In addition, in shifting their self-ascription from employees and workers to "citizens" ( $d \hat{a} n)$, the pensioners conveyed to me their subordination and acquiescence to the state's decision, despite their dissatisfaction. Yet in my view, they also implicitly invoked a sense of political

46 Interview \#1, HCMC, 17 September 2018.

47 Interview \#4, HCMC, 20 September 2018.

48 World Bank, "Inflation, Consumer Prices (Annual \%) - Vietnam," accessed 6 February 2019, https://data.worldbank.org/indicator/FP.CPI.TOTL.ZG?locations=VN.

49 It is difficult to ascertain how much more income workers could be paid if the company applied a correct wage payment, since the amount also depends on their skills, qualifications, and seniority. 
entitlement derived from the state's socialist promise of care and better welfare for the people, a promise the state has failed to deliver through the legal system.

\section{Conclusion}

This paper contributes to and advances the vibrant literature on precarious work in Asia by exploring the relationship between law-understood as aspects of legislative reforms, values and understandings derived from the law, and practices associated with law enforcement-and workers' precarious experiences. It advocates for a discussion of precarity that captures not just workers' vulnerabilities but also their agency, capacity for collective mobilization, and individual coping strategies on a daily basis. ${ }^{50}$ The paper adopts an understanding of precarity as "relational struggles" 51 between labour, capital, and the state that involve aspects of law and practices regulating workplace rights and social protection. Through an ethnographic study of state workers' life and work following economic reform in Vietnam, it has discussed whether and how law interacts with other social, political, and ideological factors in shaping workers' precarity and their responses to such conditions. While I do not seek to make generalizations about the broader condition of workers in Vietnam and other transitional Asian societies, the case study provides a typical example of experiences of insecurity and disenchantment of people living through differing ideological and regulatory systems.

In Vietnam, more than thirty years have lapsed since dổi mó i, yet its ongoing disruptive impacts upon everyday life are still acute, especially amongst those who spent their youth as privileged socialist workers and lived through various legal and economic aspects of the reform trajectories. The working life of the state workers following the restructuring of state enterprises has been fraught with disruption and uncertainty, as the state-provided entitlements and benefits they once enjoyed were either dismantled or replaced with new rules and institutions that are subject to private regulation and market forces. Their experiences of precarity extend beyond economic prospects and opportunities; they are also underpinned by notions of justice that carry remnants of the past and a contestation to new rules and structures. The discussion has captured three instances of workers' responses to precarity: their strikes and petitioning to demand wage increases and better treatment at work; their individual, self-help measures to seek early retirement; and their strategies to survive, including re-entry into the labour markets, in their retirement.

50 Gabriella Alberti et al., "In, Against and Beyond Precarity: Work in Insecure Times," Work, Employment and Society 32, no. 3 (2018): 447-457; Donatella della Porta et al., The New Social Division: Making and Unmaking Precariousness (New York: Palgrave Macmillan, 2015).

51 Lee, "China’s Precariats," 137. 
Legal reform and legal experiences on the ground have played a subtle but important role in shaping workers' precarity. Legal reform has made obsolete key values of subsistence and reciprocity embedded in socialist labour institutions and subjected workers to unfair practices of private management. The effects of law on workers' precarity lie in business' legal non-compliance, the state's failure to ensure legal enforcement, and the insufficiency of their pension benefits. Workers' everyday struggles reveal the gap between what they came to expect following several decades of service and loyalty to the state and enterprise, and what was implemented and delivered, oftentimes in the name of the law, in the later years of work and early retirement. The findings of this paper provide fruitful grounds for further exploration of the nuanced relationship between law and precarity in different contexts, with a more empirically grounded understanding of law beyond a set of state rules and formal regulations.

Griffith University, Brisbane, Australia, September 2019 